\section{Human mercury exposure and adverse health effects in the Amazon: a review}

\author{
Exposição humana ao mercúrio e efeitos adversos \\ à saúde na Amazônia: uma revisão
}

\section{${ }^{1}$ Faculdade de Ciências Farmacêuticas de Ribeirão Preto, Universidade de São Paulo, Ribeirão Preto, Brasil. 2 Centre Interdisciplinaire de Recherches sur la Biologie, la Santí, la Societé, et l'Environnement, Montréal, Canada. \\ Correspondence C. J. S. Passos Departamento de Análises Clínicas, Toxicológicas e Bromatológicas, Faculdade de Ciências Farmacêuticas de Ribeirão Preto, Universidade de São Paulo. Via do Café s/n, FCFRP, sala 085A-A, Ribeirão Preto, $S P$ 14049-903, Brasil. cjpassos@fcfrp.usp.br}

\section{Abstract}

This paper examines issues of human mercury (Hg) exposure and adverse health effects throughout the Amazon region. An extensive review was conducted using bibliographic indexes as well as secondary sources. There are several sources of $\mathrm{Hg}$ (mining, deforestation, reservoirs), and exposure takes place through inhalation or from fish consumption. There is a wide range of exposure, with mean hair-Hg levels above $15 \mu \mathrm{g} / \mathrm{g}$ in several Amazonian communities, placing them among the highest reported levels in the world today. Dietary Hg intake has been estimated in the vicinity of $1-2 \mu \mathrm{g} / \mathrm{kg} /$ day, considerably higher than the USEPA RfD of $0.1 \mu \mathrm{g} / \mathrm{kg} /$ day or the World Health Organization recommendation of $0.23 \mu \mathrm{g} /$ $\mathrm{kg} /$ day. Neurobehavioral deficits and, in some cases, clinical signs have been reported both for adults and children in relation to Hg exposure in several Amazonian countries. There is also some evidence of cytogenetic damage, immune alterations, and cardiovascular toxicity. Since fish provide a highly nutritious food source, there is an urgent need to find realistic and feasible solutions that will reduce exposure and toxic risk, while maintaining healthy traditional dietary habits and preserving this unique biodiversity.

Mercury Poisoning; Environmental Exposure; Amazonian Ecosystem
Carlos J. S. Passos 1

Donna Mergler 2

\section{Introduction}

Mercury (Hg) contamination of the large Amazon Basin has been the subject of much concern over the last two decades. In 1979, a major "gold rush" began in the Brazilian Amazon, which, over time, brought several hundred thousand persons (garimpeiros) to the region searching for riches 1. A health study conducted from 1986 to 1991 showed elevated urinary and blood Hg concentrations in miners with signs and symptoms of $\mathrm{Hg}$ intoxication 2. World attention focused on the plight of miners and those exposed to vapors from gold refining 1,2,3. Biogeochemical studies showed that these uncontrolled gold-mining activities released thousands of tons of $\mathrm{Hg}$ into the environment, and increased levels of this metal were reported in water, sediments, and fish 3,4. Gold mining became synonymous with Hg pollution 5. In the Amazon, the bioaccumulation and biomagnification of methyl-Hg in fish, as well as the link between fish consumption and elevated hair-Hg levels were made in the early 1990s 4 . Flooded forests and macrophyte mats are specific features of many areas of the Amazon and constitute important links between $\mathrm{Hg}$ inputs from natural and anthropogenic sources and methyl-Hg exposure of local populations through fish ingestion 6 . Seasonal inundation of rivers and their floodplains seems to govern the production and bioavailability of methyl-Hg to food webs 7 . 
As data accumulated on elevated levels of $\mathrm{Hg}$ in fish and human populations, even among those living far away from gold-mining activities, other primary Hg sources were proposed. Veiga et al. 8 estimated that forest fires and biomass burning could make an important contribution to the environmental Hg burden. Subsequent studies on the distribution and partition of total Hg in waters of the Tapajós River in Brazil showed that Hg content in the water column was influenced by the amount of particulate matter, independently from upstream gold-mining activities 9. Pioneering studies in the Tapajós region further showed that Amazonian soils constitute major natural $\mathrm{Hg}$ reservoirs that release substantial amounts of the metal into the aquatic ecosystems through soil erosion and leaching resulting from deforestation practices, such as "slash and burn" agriculture and/or cattle raising $10,11,12,13$. Since then, a growing number of publications has corroborated the role of deforestation and soil erosion as a major source of $\mathrm{Hg}$ release into the waterways, and hence to fishing resources and human fish-eating communities $14,15,16,17,18$. Deforestation and soil erosion resulting from gold-mining activities as well as $\mathrm{Hg}$ releases from abandoned mining sites constitute additional sources of $\mathrm{Hg}$ to the environment 19. Because of the multiple sources and continuing environmental degradation leading to elevated $\mathrm{Hg}$ in the food web, human $\mathrm{Hg}$ exposure is prevalent in numerous mining and fish-eating populations in many regions of the large Amazonian territory.

Much of our knowledge of environmental methyl-Hg clinical toxicity is strongly linked to the disasters that occurred over 40 years ago in Minamata and Niigata, Japan, as well as in Iraq 20,21 , where high levels of methyl-Hg exposure caused death and neurological damage to thousands, whowere exposed directly or in utero. These events were recently reviewed elsewhere 22,23 . Over the last decade, international public health concerns on the toxicological risks of methyl-Hg have focused almost exclusively on developmental neurotoxicity associated with prenatal exposure 24,25 . The findings of large prospective birth cohort studies have formed the basis for recent risk assessments and revision of reference doses proposed by national and international bodies 24,25. However, in most of the Amazon region, little has been done to protect mining and fisheating communities and $\mathrm{Hg}$ exposure remains elevated 26,27 .

The purpose of this paper is to examine the scientific literature on human $\mathrm{Hg}$ exposure and adverse health effects in the Amazon, with a view to understanding the implications for inter- vention, risk management, and environmental health in this developing region.

\section{Methods}

A computerized database search of MEDLINE, LILACS, SciELO, and Scopus was conducted using the following search terms: mercury, methylmercury, environmental exposure, fish consumption, occupational exposure, gold mining, deforestation, hair mercury, blood mercury, urinary mercury, toenail mercury, risk assessment, health effects, neurotoxic, immunotoxic, cardiovascular, genotoxic, diet, nutritional factors, selenium, fruit consumption, intervention, and Amazon. In addition, secondary reference searching and hand-searching were used to identify relevant primary studies and reviews dealing with biogeochemical and ecotoxicological issues, human exposure, health risk assessment and communication, human health effects, as well as dietary/nutritional studies and interventions to reduce exposure and toxicity.

In our survey of the literature, we included peer-reviewed documents, as well as published reports by international organizations dealing with policy and research programs to reduce the adverse ecological and human health impacts of Hg pollution. The bibliographic research covered articles and reports written in English, Portuguese, Spanish, and French.

In all, we examined 24 primary studies covering the anthropogenic and natural sources of $\mathrm{Hg}$ into the environment and related ecotoxicological issues. Fifty-four studies addressed questions relating to human exposure in mining, riparian, indigenous, and urban populations, while only eight studies assessed health risk and communication. Human health outcomes were examined in 34 studies, and a limited amount of work was retrieved on community-based interventions and dietary, nutritional, and genetic factors that could influence Hg exposures in the Amazon. For the sake of comparison, 42 primary studies and review papers as well as authoritative sources analyzing $\mathrm{Hg}$ issues around the globe are also included in the present report.

\section{Results and discussion}

\section{Mercury exposure in the Amazon Basin}

Hair-Hg is generally considered to be a good indicator of $\mathrm{Hg}$ exposure through fish consumption 22,25 , and many studies in the Amazon have examined hair-Hg concentrations in occupational 
settings at gold-mining and refining sites (see Da Silva 28 for location of the most important sites) and for environmental exposures in urban and remote riparian and indigenous settlements. Table 1 provides a chronological summary by country for studies conducted in several Amazon watersheds and cities. The first published assessment of hair-Hg levels was made in gold miners and dates back to 1988 in the Brazilian literature 29, while Malm et al. ${ }^{4}$ published the first evaluation in remote riparian villagers, for communities along the Madeira River. Around the same time, Boischio \& Barbosa 30 reported that of 311 hair samples analyzed in the Madeira River area, 51\% had $\mathrm{Hg}$ levels over $10 \mu \mathrm{g} / \mathrm{g}$, with wide inter-individual variations and concentrations as high as $303 \mu \mathrm{g} / \mathrm{g}$. To our knowledge, Malm et al. ${ }^{4}$ published the first report that recognized fish consumption as the exposure route for communities not living in the vicinity of gold-mining sites. Since those initial studies, consistently elevated hair-Hg levels have been reported in different watersheds of the Brazilian Amazon Basin. In 1995, Olivero et al. 31 reported elevated hair-Hg levels in a mixed population living in a mining area of the Colombian Amazon, with fishermen showing higher levels than miners, and in 1998 a study in French Guiana, another Amazonian country, likewise revealed elevated $\mathrm{Hg}$ levels in fish consumers of different ethnic groups 32 . Elevated hair-Hg concentrations have since been reported for the Amazonian areas of Bolivia, Ecuador, and Suriname 33,34,35,36.

Among fish consumers, riparian communities present the highest degree of exposure, with mean hair-Hg as high as $38.6 \pm 14.4 \mu \mathrm{g} / \mathrm{g} 37$ and $65 \pm 58 \mu \mathrm{g} / \mathrm{g} 38$. Overall, urban fish-consumers are the least exposed, presenting mean hair-Hg levels of $2.4 \mu \mathrm{g} / \mathrm{g} 39,2 \mu \mathrm{g} / \mathrm{g} 40$, and $1.9 \mu \mathrm{g} / \mathrm{g} 34$. However, a recent pilot study in two municipalities of the Negro River in the Brazilian Amazon (São Gabriel da Cachoeira and Barcelos) showed mean hair-Hg levels of $13 \mu \mathrm{g} / \mathrm{g}$ and $9.7 \mu \mathrm{g} / \mathrm{g}$, with upper values as high as $81.3 \mu \mathrm{g} / \mathrm{g} 41$.

Some studies have provided information on the percentage of methyl-Hg in hair samples (Table 1). Methyl-Hg is generally above $70 \%$, but a few studies show wider variations. In three pregnant women from French Guiana with exceptionally elevated hair-Hg $(88 \mu \mathrm{g} / \mathrm{g}, 420 \mu \mathrm{g} / \mathrm{g}$, and $530 \mu \mathrm{g} / \mathrm{g}$ ), speciation of $\mathrm{Hg}$ showed that it was mainly inorganic Hg; the authors suggested that this probably resulted from direct exposure to metallic $\mathrm{Hg}$ in the household 32 . Indeed, pregnant women constitute a group deserving particular attention since $\mathrm{Hg}$ crosses the placenta to the fetus, and methyl-Hg is actively transferred $42,43,44$.
In the Amazonian mining communities, urinary $\mathrm{Hg}$, considered the most valid bioindicator for exposure from inhalation of elemental $\mathrm{Hg}$ vapors 22 , has been assessed in several studies. In this region, gold-Hg amalgam burning has contributed to substantial Hg exposure, with urinary $\mathrm{Hg}$ values ranging from 0.2 to $663 \mu \mathrm{g} / \mathrm{L}$ in adults $2,45,46,47,48,49$, while in children concentrations from 26 to $159 \mu \mathrm{g} / \mathrm{L} 35,50$ have been reported. More recently, and consistent with recent findings in other areas of the world 51,52,53,54,55, fisheating has been associated with relatively elevated urinary $\mathrm{Hg}$ in non-occupationally exposed populations in the Brazilian Amazon. Passos et al. 56 reported urinary $\mathrm{Hg}$ levels above $10 \mu \mathrm{g} / \mathrm{L}$ for almost $20 \%$ of a population with no evidence of exposure from $\mathrm{Hg}$ vapors; in that study, elevated urinary $\mathrm{Hg}$ was associated with consumption of carnivorous fish.

\section{Mercury sources, fishing resources, and bioindicators of exposure}

Identification of $\mathrm{Hg}$ sources is particularly important for mitigation, and elevated $\mathrm{Hg}$ levels in Amazonian communities probably reflect a multiplicity of sources releasing $\mathrm{Hg}$ into the environment and fishing resources. While in some areas of Colombia, Suriname, and Venezuela, $\mathrm{Hg}$ from gold mining most likely predominates over deforestation and/or hydroelectric damns $31,36,57$, in other regions, such as Peru, it is difficult to ascertain whether fish-Hg contamination is attributable to mining or other causes 58 , and in countries like Brazil, Ecuador, and Bolivia there seems to be an interplay of various sources $17,18,26,33,59,60$ that contribute synergistically to environmental and aquatic biota contamination, as recently proposed in the French Guiana Amazon 19.

The recent study in the Negro River, cited above, provides an interesting illustration of possible multiple sources. While the authors point to gold mining in the Upper Negro River (Colombian Amazon) as the probable source, recent biogeochemical studies have shown the important impact of naturally occurring $\mathrm{Hg}$ in this basin 14,61,62, concluding that $\mathrm{Hg}$ leaching from soils constitutes the largest regional reservoir of this metal 14 . These findings are supported by studies analyzing environmental determinants of $\mathrm{Hg} \mathrm{lev-}$ els in fish as well as dietary human exposure, all of which indicate that fish and human Hg levels in the Negro River Basin are strongly influenced by naturally high background Hg levels 37,63,64. However, it is difficult to ascertain the true source of exposure (which may not be unique) for each community, and the variation in results from 
Reported hair-Hg levels in fish-eating groups in the Amazon Basin

\begin{tabular}{|c|c|c|c|c|c|c|c|}
\hline \multirow[t]{2}{*}{ Location } & \multirow[t]{2}{*}{ Population } & \multirow[t]{2}{*}{ Age (years) } & \multirow[t]{2}{*}{$\mathrm{n}$} & \multicolumn{2}{|c|}{ Total hair-Hg $(\mu \mathrm{g} / \mathrm{g})$} & \multirow{2}{*}{$\begin{array}{l}\% \mathrm{MeHg} \\
\text { (Range) }\end{array}$} & \multirow[t]{2}{*}{ Reference } \\
\hline & & & & Mean \pm SD & Range & & \\
\hline \multicolumn{8}{|l|}{ Brazil } \\
\hline Madeira River & Riparian & - & 713 & $15.2 \pm 9.6$ & $6-150$ & - & Bastos et al. 26 \\
\hline Tapajós River & Riparian & $<15$ to 65 & 69 & $\cong 15 \pm N A$ & - & - & Pinheiro et al. 27 \\
\hline Madeira River & Riparian & - & 241 & $17.2 \pm \mathrm{NA}$ & NA-303 * & $\star \star$ & Boischio \& Barbosa 30 \\
\hline Xingu Park & Indigenous & - & 27 & $18.5 \pm 5.9$ & 6.9-34 & - & Vasconcelos et al. 154 \\
\hline Cuniã Lake Reserve & Riparian & - & 75 & $8.7 \pm N A$ & NA-31.9 & $70-80$ & Barbosa et al. 45 \\
\hline Fresco River & Indigenous & - & 419 & $8.0 \pm N A$ & - & - & Barbosa et al. 45 \\
\hline Tapajós River & Riparian & - & 101 & $21 \pm N A$ & $4.7-151$ & $85-91$ & Malm et al. 65 \\
\hline Santarém City & Urban & - & 10 & $2.7 \pm N A$ & - & - & Malm et al. 65 \\
\hline Gurupi goldfield & Riparian & - & 10 & - & $0.2-15$ & - & Palheta \& Taylor 46 \\
\hline Negro River & Riparian & - & 101 & $38.6 \pm 14.4$ & - & - & Eve et al. 37 \\
\hline Teles Pires and Juruena Rivers & Indigenous & - & 55 & $34.2 \pm N A$ & 10 to $>50$ & 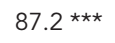 & Barbosa et al. 66 \\
\hline Yanomami Indians & Indigenous & - & 14 & $3.3 \pm 1.2$ * & $1.5-6.0$ * & $58-97$ & Kehrig et al. 67 \\
\hline Tapajós and Madeira Rivers & Riparian & - & 82 & $16.7 \pm 7.3$ * & $1.0-59.4$ * & $8.7-100$ & Kehrig et al. 67 \\
\hline Tapajós River & Riparian & $\geq 15$ & 96 & $12.9 \#$ & $0-145$ & $73-94$ & Lebel et al. 68 \\
\hline Fresco River & Indigenous & $<2$ to 45 & 28 & $8.1 \pm 3.2$ & $0.8-13.7$ & - & Barbosa et al. 155 \\
\hline Madeira River & Riparian & $<2$ to 45 & 98 & $14.1 \pm 10.7$ & $2.6-94.7$ & - & Boischio \& Cernichiari 156 \\
\hline Madeira River & Riparian & $0.1-32$ & 28 & - & $4.0-84.4$ & $84-90$ & Barbosa et al. 155 \\
\hline Pracuúba Lake & Riparian & - & 15 & $16.7 \pm \mathrm{NA}$ & - & - & Guimarães et al. 75 \\
\hline Alta Floresta City & Urban & $14-45$ & 75 & $1.1 \pm 1.17$ & $0.1-8.2$ & - & Hacon et al. 70 \\
\hline Tapajós River & Riparian & - & - & $17 \pm 8.5$ & $2.9-71.5$ & - & Pinheiro et al. 71 \\
\hline Xingu Park & Indigenous & - & - & $13.6 \pm 4.7$ & $4.3-32.8$ * & - & Vasconcelos et al. 118 \\
\hline Negro River & Riparian & $<15$ to 40 & 76 & $21.4 \pm 12.7$ & $1.7-59$ & $34-100$ & Barbosa et al. 157 \\
\hline Tapajós River & Riparian & $12-68$ & 36 & $12.5 \#$ & $2.9-27$ & - & Dolbec et al. 72 \\
\hline Rio Branco City & Urban & 0 to $>60$ & 2,318 & $2.4 \pm 3.9$ & $0.8-72.7$ & - & Santos et al. 39 \\
\hline Tapajós River & Riparian & $<1$ & - & $12 \pm N A$ & $9.6-14.6$ & - & Boischio et al. 158 \\
\hline Santarém City & Urban & $17-25$ & 44 & $2.0 \pm 1.8$ & $0.08-15.2$ & - & Passos et al. 40 \\
\hline Pakaanóva Indians & Indigenous & $0.5-90$ & 910 & $8.4 \pm 6.4$ & $0.5-83.9$ & - & Santos et al. 73 \\
\hline Tapajós River & Indigenous & $<10$ & 203 & $8.1 \pm 5.2$ & - & - & Dórea et al. 159 \\
\hline Negro River & Urban & - & 399 & $11.4 \pm$ NA & $0.1-83.1$ & - & Santos et al. 41 \\
\hline Tapajós and Tocantins Rivers & Riparian & $0.1-12$ & 168 & $5.1 \# \#$ & $0.4-53.8$ & - & Pinheiro et al. 160 \\
\hline \multicolumn{8}{|l|}{ French Guiana } \\
\hline Maroni and Oyapock Rivers & Indigenous & $<15$ to 80 & 156 & $5.4 \# \#$ & $0.2-530$ & - & Cordier et al. 32 \\
\hline Maroni River & Indigenous & 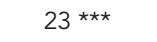 & 235 & $11.4 \pm 4.2$ & $1.9-27.2$ & - & Fréry et al. 76 \\
\hline \multicolumn{8}{|l|}{ Bolivia } \\
\hline Beni River & Indigenous & - & 80 & $9.8 \pm N A$ & $4.3-19.5$ & - & Maurice-Bourgoin et al. 33 \\
\hline \multicolumn{8}{|l|}{ Colombia } \\
\hline San Jorge River & Riparian & $15-65$ & 94 & $4.9 \pm 0.55$ & $0.5-40$ & - & Olivero et al. 31 \\
\hline \multicolumn{8}{|l|}{ Ecuador } \\
\hline Napo River Valley & Urban & - & 46 & $1.9 \pm N A$ & $0.03-10$ & - & Webb et al. 34 \\
\hline Napo River Valley & Indigenous & - & 54 & $7.0 \pm N A$ & $1.5-13.6$ & - & Webb et al. 34 \\
\hline Nambija mining area & Indigenous & $0-14$ & 80 & $6.0 \pm 17.5$ & $1.0-135$ & - & Counter et al. 35 \\
\hline
\end{tabular}

NA: not available.

* Hair MeHg;

** Authors indicate that $70 \%$ of a sub-sample had $>80 \% \mathrm{MeHg}$;

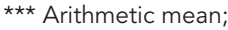

\# Median;

\#\# Geometric mean. 
communities in the Negro River basin might depend upon where sampling was performed.

No matter what the environmental source, fish-eating practices are the most important predictor of $\mathrm{Hg}$ exposure in most areas of the Amazon, explaining a substantial proportion of the variation of total and methyl-Hg concentrations in both blood and hair. Based on these bioindicators, as well as $\mathrm{Hg}$ measurements in fish tissue, many studies in the Amazon have associated $\mathrm{Hg}$ exposure with fish consumption 4,26,27,32,33,37,39,45, $46,65,66,67,68,69,70,71,72,73,74$, especially for members of fishing families $75,76,77$. These studies support the universal observation that fish consumption constitutes the most important source of Hg exposure worldwide 22,25. What distinguishes communities in the Amazon from many others around the world is that for an important proportion of this population, fish is the dietary mainstay and many eat fish at least once a day 68,72.

Studies on $\mathrm{Hg}$ in fish have noted a sizeable variation in concentrations among a large number of species, ranging from 0.01 up to $3.77 \mu \mathrm{g} / \mathrm{g}$, depending on the feeding habits and location $26,33,65,68,69$. There are, however, few studies of $\mathrm{Hg}$ speciation in fish from the Amazon region. Notable exceptions are Kehrig et al. 69 and Maurice-Bourgoin et al. 33 who respectively reported methyl-Hg fractions above $95 \%$ and varying from $73 \%$ to $98 \%$ of the total $\mathrm{Hg}$ in fish from the Balbina Reservoir and the Madeira River areas. Recent studies of total fish-Hg concentrations in the Amazon have also stressed the particular influence of annual flooding 64,78 and the role of fish species' food regimes 79,80 on the bioaccumulation patterns in the different ecosystems.

Investigators who examined the strength of associations between fish consumption frequency and hair-Hg concentrations $31,38,40,68,72$ have shown correlation coefficients ranging from 0.2 to 0.89 , depending on the frequency of fish intake as well as the fish species consumed. In addition, significant seasonal differences in hair-Hg levels have been reported for villages on the Tapajós River 68,72 , where water levels can vary by around six meters between the rainy and dry seasons, affecting fish habitats and the availability of specific fish species. In contrast, no seasonal variations were observed for communities in the Andean Amazon 34, although the local habits of fish consumption as well as the different fish-eating patterns among communities were important determinants of exposure.

\section{$\underline{\text { Risk assessment studies }}$}

Given the elevated levels of exposure, some researchers have attempted to estimate the rates of $\mathrm{Hg}$ intake for purposes of health risk assessment. Table 2 lists studies that measured daily fish and $\mathrm{Hg}$ intake rates in different settings. Large amounts of fish are consumed throughout the Amazon; average daily intake in one area was around $340 \mathrm{~g} /$ day and reached up to more than $600 \mathrm{~g} /$ day in periods of abundance 76 . For many in the Amazonian watershed, fish constitutes the dietary mainstay, with intake depending on cultural practices and seasonal availability of this food. Different investigators have estimated the health risks of $\mathrm{Hg}$ exposure using predictive models.

Kehrig et al. 69 estimated that the population living near the Balbina Reservoir ingested 35.2 $\mu \mathrm{g}$ of methyl-Hg during the whole year, while Fréry et al. 76 , who performed extensive calculations using data from fish-Hg concentrations as well as amounts and frequency of fish consumed by each household, estimated $\mathrm{Hg}$ intake between 40 and $60 \mu \mathrm{g} /$ day. Others have presented estimates in $\mu \mathrm{g} / \mathrm{kg} /$ day. These $\mathrm{Hg}$ intake rates, presented in Table 2, range from 0 to more than $4 \mu \mathrm{g} / \mathrm{kg} /$ day, largely exceeding the exposure limit for $\mathrm{Hg}$ intake of $0.23 \mu \mathrm{g} / \mathrm{kg} /$ day, recently revised by the World Health Organization (WHO) 24.

Hacon et al. 77 and Boischio \& Henshel 81 also estimated potential health risks, using hazard quotients (HQ) based on the ratio of the estimated dose rate to the selected reference dose. If HQ is less than one, there is no anticipated risk of adverse effects, while there is a possibility of such risks in sensitive groups if it is equal to or greater than one 77 . Using a reference dose of $0.3 \mu \mathrm{g} / \mathrm{kg} /$ day, these studies showed that the highest hazard quotients were observed for the riparian populations of the Madeira River 77,81.

\section{Human health studies}

Over the last decade a number of human health studies have been carried out in different Amazonian communities. We identified 34 studies, of which the majority was conducted in the Brazilian Amazon (82\%). Sixty-three percent focused on adult populations, while $24 \%$ examined children and $12 \%$ surveyed both adults and children. All of the studies used cross-sectional designs. Neurotoxic outcomes were the most extensively examined: $36 \%$ attempted to identify clinical neurological signs of $\mathrm{Hg}$ intoxication, while $42 \%$ tested the hypothesis of long-term low-dose exposure as a risk factor for neurobehavioral deficits at the population level. The remaining $12 \%$ included cytogenetic damage and more recent emerging evidence on immune and cardiovascular effects. 
Summary of risk assessment studies in Amazonian settings.

\begin{tabular}{|c|c|c|c|c|c|c|c|}
\hline Location & Setting & Fish intake & $\begin{array}{c}\text { Total } \\
\text { population }\end{array}$ & $\begin{array}{l}\text { Hg intake } \\
\text { Women }\end{array}$ & Children & $\begin{array}{c}\text { Mean hazard } \\
\text { quotient }\end{array}$ & Reference \\
\hline Madeira River & Riparian & 200 g/day & $2.2 \mu \mathrm{g} / \mathrm{kg} /$ day & $1.2 \mu \mathrm{g} / \mathrm{kg} /$ day * & $6.4 \mu \mathrm{g} / \mathrm{kg} /$ day ** & $\begin{array}{c}\text { Women: } \\
0.02 \text {; children: } 21\end{array}$ & Boischio \& Henshel 81 \\
\hline Tartarugalzinho River & Riparian & 200 g/day & $1.6 \mu \mathrm{g} / \mathrm{kg} /$ day & - & - & - & Bidone et al. 161 \\
\hline Alta Floresta City & Urban & $\begin{array}{c}\text { General } \\
\text { population: } \\
\text { 8g/day; } \\
\text { children: } \\
\text { 5g/day; fisher } \\
\text { families: } \\
\text { 110g/day }\end{array}$ & $\begin{array}{c}\text { Fisher } \\
\text { families: } \\
2.2 \mu \mathrm{g} / \mathrm{kg} / \text { day }\end{array}$ & - & $\begin{array}{c}\text { Fisher } \\
\text { families: } \\
3.5 \mu \mathrm{g} / \mathrm{kg} / \text { day }\end{array}$ & $\begin{array}{c}\text { General } \\
\text { population: } \\
\text { 1.4; fisher } \\
\text { families: } \\
8.6\end{array}$ & Hacon et al. 77 \\
\hline $\begin{array}{l}\text { Barbina Reservoir } \\
\text { village }\end{array}$ & Riparian & $110 \mathrm{~g} /$ day & $35.2 \mu \mathrm{g} / \mathrm{y}$ & - & - & - & Kehrig et al. 69 \\
\hline Madeira River & Riparian & $243 \mathrm{~g} /$ day & $2.6 \mu \mathrm{g} / \mathrm{kg} /$ day & - & - & - & Boischio \& Henshel 128 \\
\hline Upper Maroni River & Indigenous & $163.1 \mathrm{~g} /$ day & 40-60 $\mu \mathrm{g} /$ day & $41.4 \mu \mathrm{g} /$ day & $17.5 \mu \mathrm{g} /$ day & - & Fréry et al. 76 \\
\hline $\begin{array}{l}\text { Northern Mato Grosso } \\
\text { State Municipalities }\end{array}$ & Urban & - & $0.01-3.9 \mu \mathrm{g} / \mathrm{kg} /$ day & - & - & - & Hacon et al. 162 \\
\hline Tapajós River & Riparian & $141 \mathrm{~g} / \mathrm{meal}$ & $0-4.3 \mu \mathrm{g} / \mathrm{kg} /$ day & - & - & - & Passos et al. 122 \\
\hline
\end{tabular}

* 15-48 years old;

$\star \star<5$ years old.

\section{- Neurotoxic effects}

Table 3 summarizes the results of studies that examined associations between exposure and neurofunctional deficits in fish-eating communities. The first studies showing neurotoxic effects in adults below $50 \mu \mathrm{g} / \mathrm{g}$ hair-Hg were conducted in the Amazon. In these studies, significant dose-effect associations were reported for motor, visual, and/or cognitive functions $82,83,84,85,86$. Two studies of children identified deficits in attention and visuo-spatial performance, as well as poorer leg coordination 87,88 , whereas two other studies in children did not detect effects 89,90 . These latter negative studies examined riparian and urban children respectively, with substantially lower levels of exposure compared to other Amazonian communities; both used different neurobehavioral and statistical approaches from previous investigations, which makes it difficult to compare their findings with the others. On the other hand, the positive findings in the Amazon child studies are consistent with other investigations conducted around the world, such as the prospective cohort studies in the Faeroe Islands and New Zealand 91,92,93 and cross-sectional investigations in the Canadian Arctic and Japan 94,95.
In the Amazon region, $\mathrm{Hg}$ exposure has been inversely associated with hearing threshold as well as auditory brainstem evoked responses in both children and adults living in the Nambija gold mining area of Ecuador 96,97. Although the study population lived in a mining area, the authors suggest that these persons may be at neurological risk not only from elemental $\mathrm{Hg}$ vapors inhaled during amalgam burning, but also from Hg exposure through consumption of foods with elevated $\mathrm{Hg}$. In another study conducted in the Brazilian Amazon, auditory deficits were not observed for children and adolescents exposed through fish consumption 98 . It is difficult to determine whether differences in exposure (inorganic $\mathrm{Hg}$ vapors vs. dietary methyl-Hg) are the underlying reason for the inconsistencies.

Other investigators have used clinical methods including neurological examinations to identify typical symptoms of methyl-Hg poisoning (e.g. glove- and-stocking-type sensory disorder, visual field constriction, tremor, and cognitive disorders such as difficulty in concentrating and recent memory losses). We identified seven clinical cross-sectional studies of fish-eating communities, of which two reported neurological deficits related to $\mathrm{Hg}$ exposure, includ- 
Summary of neurobehavioral outcomes examined in relation to hair-Hg levels in Amazonian fish-eating communities.

\begin{tabular}{|c|c|c|c|c|c|c|c|c|c|}
\hline & \multicolumn{5}{|c|}{ Adult population } & \multicolumn{4}{|c|}{ Child population } \\
\hline & $\begin{array}{l}\text { Lebel } \\
\text { et al. } 82\end{array}$ & $\begin{array}{l}\text { Lebel } \\
\text { et al. } 83\end{array}$ & $\begin{array}{l}\text { Dolbec } \\
\text { et al. } 84\end{array}$ & $\begin{array}{l}\text { Yokoo } \\
\text { et al. } 85\end{array}$ & $\begin{array}{l}\text { Silveira } \\
\text { et al. } 86\end{array}$ & $\begin{array}{c}\text { Grandjean } \\
\text { et al. } 87\end{array}$ & $\begin{array}{l}\text { Cordier } \\
\text { et al. } 88\end{array}$ & $\begin{array}{l}\text { Tavares } \\
\text { et al. } 89\end{array}$ & $\begin{array}{l}\text { Marques } \\
\text { et al. } 90\end{array}$ \\
\hline Hair Hg $(\mu \mathrm{g} / \mathrm{g})$ & 14 * & $\cong 13$ ** & $11 \pm 6$ *** & 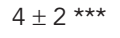 & $0.6-72 \#$ & 11 * & 10.2 * & 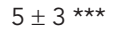 & 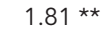 \\
\hline Color vision & $\downarrow \# \#$ & $\downarrow$ & - & - & $\downarrow \# \#$ & - & - & - & - \\
\hline Near visual contrast sensitivity & $\downarrow$ & $\downarrow \# \#$ & - & - & $\downarrow \# \#$ & - & - & - & - \\
\hline Grip strength & $\downarrow$ & $\downarrow$ & - & - & - & - & - & - & - \\
\hline Muscular fatigue & $\uparrow$ & $\uparrow$ & - & - & - & - & - & - & - \\
\hline Visual field & $\downarrow$ & $\downarrow \# \#$ & - & - & - & & - & - & - \\
\hline Manual dexterity & $\downarrow \# \#$ & $\downarrow \# \#$ & $\downarrow \# \#$ & - & - & $\downarrow \# \#$ & - & - & - \\
\hline Fine motricity & - & - & $\downarrow \# \#$ & $\downarrow \# \#$ & - & $\downarrow \# \#$ & $\downarrow$ & - & - \\
\hline Logical memory & - & - & - & $\downarrow \# \#$ & - & - & - & - & - \\
\hline Digit span & - & - & - & $\downarrow \# \#$ & - & $\downarrow \# \#$ & $\downarrow \# \#$ & - & - \\
\hline Easy learning & - & - & - & $\downarrow \# \#$ & - & - & - & - & - \\
\hline Concentration & - & - & - & $\downarrow \# \#$ & - & - & - & - & - \\
\hline Visuospatial functions & - & - & - & - & - & $\downarrow \# \#$ & $\downarrow \# \#$ & - & - \\
\hline Leg coordination & - & - & - & - & - & & $\downarrow \# \#$ & - & - \\
\hline Static balance & - & - & - & - & - & - & - & NS & - \\
\hline Dynamic balance & - & - & - & - & - & - & - & NS & - \\
\hline Appendicular coordination & - & - & - & - & - & - & - & NS & - \\
\hline Motor persistence & - & - & - & - & - & - & - & NS & - \\
\hline Trunk-limb coordination & - & - & - & - & - & - & - & NS & - \\
\hline Sensory perception & - & - & - & - & - & - & - & NS & - \\
\hline Gesell developmental schedules & - & - & - & - & - & - & - & - & NS \\
\hline
\end{tabular}

NS: non-significant.

* Geometric mean;

** Median;

*** Arithmetic mean and standard deviation;

\# Range;

\#\# Statistically significant.

ing sensory and balance disturbances, tremor, hyperreflexia, dysarthria 99,100. In addition, the study by Lebel et al. 83 on fish-eaters from the Tapajós Basin included a neurological examination showing that although participants had normal results on most items, those with higher hair-Hg levels presented a significantly high prevalence of disorganized movements on the Branches Alternate Movement Task (BAMT) as well as restricted visual fields. The BAMT, which requires the individual to perform coordinated hand-knee movements, continually passing one arm over the other as rapidly as possible 83, was developed by Dr. Fernando Branches, a physician and pioneer in Hg neurotoxicity in the Brazilian Amazon 2,65,83. Impaired BAMT performance has also been observed in connection with low $\mathrm{Hg}$ exposures through fish consumption as well as with occupational exposures in Italian cohorts 101,102. The results of the clinical investigations of
Amazonian communities provide supplementary evidence of $\mathrm{Hg}$ neurotoxicity, despite the nonspecific nature of several signs.

\section{- Non-neurological outcomes}

Only one study has reported cytogenetic damage (decreased mitotic index and increased frequency of polyploid cells) related to hair-Hg levels in a fish-eating community on the Tapajós River 103. In a follow-up of this population, five years later, after a $40 \%$ decrease in hair-Hg levels, the same cytogenetic endpoints no longer displayed significant associations with hair-Hg. The authors suggest that this is consistent with reduced biological impact resulting from the decrease in $\mathrm{Hg}$ exposure 104 . However, there is a lack of evidence in the literature concerning the association of both organic and inorganic $\mathrm{Hg}$ with cytogenetic outcomes, and more studies are needed to con- 
firm these relations with early biomarkers of cytogenetic damage.

Some recent studies have focused on possible immune outcomes associated with Hg exposure. One epidemiological study reported that even if no relation was observed between bioindicators of $\mathrm{Hg}$ exposure and prevalent malaria, the odds ratio for reporting past malaria infection was four times higher for those also reporting a history of working with inorganic $\mathrm{Hg}$ 105. Further investigation of the relationship between $\mathrm{Hg}$ exposure and prevalent malaria in the Amazon has produced consistent results in terms of $\mathrm{Hg}$-induced effects on biomarkers of autoimmunity. One study reports on immune changes indicative of autoimmune dysfunction in environmentally exposed villagers 106 , and another investigation shows that positive serum antinuclear antibodies are more frequently observed in riparian fish-eaters than in low fish consumers from an urban area 107. The experimental and human evidence of possible inorganic Hg-induced immunological alterations 108 are particularly important in the Amazon, since these traditional populations (riparian and indigenous) are concomitantly exposed to vector-borne diseases such as malaria and Chagas infection.

Only two studies have analyzed cardiovascular outcomes in relation to $\mathrm{Hg}$ in the Amazon; one examined four indigenous villages 109 and the other surveyed six riparian communities on the Tapajós 110. Dórea et al. 109 reported that while no significant differences in body mass index were observed between villages, there was a trend towards a lower increase in blood pressure with age among the higher fish consumers. On the other hand, Fillion et al. 110 showed blood pressure directly and significantly associated with total hair-Hg levels, and no association between fish consumption and blood pressure. A multi-center case-control study among men 70 years old or younger from eight European countries and Israel showed toenail-Hg levels directly associated with the risk of myocardial infarction, while an inverse association was observed with adipose-tissue docosahexaenoic acid (DHA) 111. Although it is difficult to compare this study to the ones on cardiovascular outcomes in the Amazon, given the higher levels of exposure in many Amazonian communities as compared to North American and European cohorts 111,112, and because of possible toxicokinetic interactions promoted by traditional diet 113,114,115, future epidemiological studies should attempt to include a wider range of cardiovascular endpoints and further examine the possible influence of dietary and genetic factors.

\section{The role of dietary and nutritional factors}

In the Seychelles Islands cohort study of childhood neurodevelopment, some results suggest beneficial outcomes correlated with $\mathrm{Hg}$ levels during pregnancy, which was interpreted as a possible protective effect of fish-borne nutrients 42 , although no specific nutrient was identified. There is a growing interest in candidate nutrients that could protect against $\mathrm{Hg}$ absorption and/or toxicity 116 .

Because of protective effects observed in a certain number of animal studies, selenium (Se) has received the most attention as a potential protector against Hg toxicity in populations consuming seafood 117. A few studies have analyzed blood and/or hair-Se concentrations among fish-eating communities in areas of the Brazilian Amazon 118,119,120,121. While most are in the normal range, Lemire et al. ${ }^{121}$ reported elevated blood-Se concentrations for a group of persons in one village, suggesting that there may be wide variations throughout the region. There are some reports 118,119,121 of positive relations between bioindicators of Se and Hg, suggesting that fish may constitute a source of dietary Se. Although the authors of these studies point out that Se may play a role with respect to Hg toxicity, no investigation has been carried out so far.

Recent studies by Passos et al. 113,114,115,122 show that the strong relationship between fish consumption and $\mathrm{Hg}$ exposure is significantly modified by fruit consumption, which may indicate possible toxicokinetic interactions promoted by fruit intake 122 . Despite general recognition of the antioxidant properties of many nutrients contained in fruits 123 , including Amazonian fruits $124,125,126,127$, this food has received little attention as a dietary factor with potential to counteract $\mathrm{Hg}$ exposure and/or toxicity. And yet, fruit gathering and consumption are repeatedly reported by many studies addressing $\mathrm{Hg}$ issues in traditional communities of the Amazon 26,33,37,128,129,130. Fruit is a particularly important component of riparian and indigenous diets, contrary to the diet of communities occupationally exposed in the mining areas 131 . Notwithstanding the encouraging and promising results concerning the role of fruits on $\mathrm{Hg}$ exposure, the studies conducted so far have not examined the possible physiological events that may be involved in the interactions between fruit nutrients and $\mathrm{Hg}$ absorption, and the potential protective effect of fruit intake with respect to toxicological outcomes also remains to be demonstrated. 


\section{Methodological challenges}

Exposure and health studies in the Amazon are methodologically challenging. Villages are often located in remote areas, with few or no health facilities and often with little or no electricity. There is a high prevalence of tropical diseases, such as malaria and different intestinal parasites. Recruitment of study participants can be difficult due to cultural and religious beliefs within the communities and/or mistrust of outsiders. Educational level is low. Study designs need to consider these factors in determining sampling strategies for bioindicators of exposure, questionnaire design for comprehension, face validity and inclusion of potential covariates, validation and administration, and testing procedures (particularly for neurobehavioral testing). Information, such as medical history that can only be collected from individual reporting, may suffer from differences in understanding, and validation against medical records is not possible in the absence of health facilities.

To date, all of the Amazonian studies have used cross-sectional designs, with most of them based on convenience samples due to the difficulties associated with random sampling strategies in these areas. However, since Hg exposure is not obvious and the effects are often not physically evident, selection bias with respect to $\mathrm{Hg}$ exposure and effects is probably not a major problem. Moreover, relations are consistent between fish consumption and/or proximity or involvement of gold-mining activities and the appropriate bioindicators of $\mathrm{Hg}$ exposure. In the neurobehavioral and neurological studies, persons with a history of disease unrelated to Hg exposure that might affect test outcomes, such as stroke, loss of consciousness over a long period, birth trauma (for studies in children), and others were excluded from most investigations either $a$ priori or post hoc $82,83,84,85,87,88$.

Hair has been the most extensively used bioindicator for $\mathrm{Hg}$ exposure in the Amazon region, and when hair and blood were both assessed, they have been shown to be highly correlated 84,115 . Hair sampling is particularly appropriate for studies in remote areas of the Amazon because it can be easily preserved and transported. However, in gold-burning areas and in the season when brush and forest are burned during farming (traditional "slash-and-burn" practices), there may be external Hg contamination. In the Amazon, toenails have not been used as a bioindicator for exposure. Although toenail-Hg has been correlated with hair and urine $\mathrm{Hg}$ levels 55, the related period of exposure is not known. Moreover, this bioindicator might not be appropriate for the Amazon setting, because in many areas people go barefoot or wear sandals, and soil-Hg may constitute a source of external contamination. For the studies reviewed here, hair-Hg was the most widely used bioindicator of exposure (76\%), followed by blood (21\%) and urinary $\mathrm{Hg}$ concentrations (12\%).

For neurobehavioral and neurological outcomes, different tests and examinations have been used in the different studies. However, there is a commonality of effects observed in the adult studies, with motor coordination and visuo-motor performance showing the most consistent associations with Hg exposure $82,83,84,85,86$. The cultural appropriateness of the tests used in these studies has been criticized 100, but the expected variation in results with age and schooling tend to indicate that the tests were understood and performed in a similar way to other populations. In studies of children, a wide range of tests has been used and thought to be culturally appropriate for children living in these settings 87,88 . While this may not necessarily be the case, it should be noted that in studies that examined similar domains to those shown to be associated with $\mathrm{Hg}$ in other areas of the world, there were similar associations with bioindicators of $\mathrm{Hg}$ exposure 87,88 . One of the issues that none of these studies can answer is the relative contribution of intrauterine and current exposure to the observed relations.

In analyzing results, most studies that examined the relations between bioindicators of exposure and effects took age and schooling into account (where relevant); other factors such as smoking, alcohol consumption, malaria, working in gold-mining areas, and others identified through regression analyses have been included in the multiple regression models for the adult studies $82,83,84,85,86$. For the children's studies, potential covariates have been examined in some studies; these include maternal education, illness during childhood, parity, maternal age at delivery, maternal education, household income, illness during pregnancy, and duration of breastfeeding ${ }^{88}$. Some studies have included basic clinical examinations, which provide an indication of health status $83,88,89,90,97,99,100,105,106,109$. In studies which cover several villages, educational level may reflect different realities since it is very dependent on the local system and teachers, although place of birth or residence, which can reflect different exposures and/or different socioeconomic and cultural situations, have been included in some of the studies $87,88,110$. Despite the inclusion of a wide range of potential covariates in several studies, certain covariates (most notably dietary factors) may not have been iden- 
tified or assessed, and were thus not included in the regression models.

Recent studies have underscored the benefits of fish nutrients as possible confounders and/or modifiers of relations between $\mathrm{Hg}$ exposure and health effects. Indeed, fish-borne nutrients such as DHA, iodine, iron, and choline have been considered potential modifiers of the effects of methyl-Hg on child outcomes in the Seychelles' studies 116. Possible toxicokinetic interactions promoted by fruit intake, not only in Amazonian but most probably for other fish-eating populations where fruit is an important component of diet, might also constitute an effect modifier $113,114,115,122$ and should be taken into account in future studies. To our knowledge, there is no published data on fatty acid levels in fish or humans in the Amazonian region, and this information would be useful for further investigations.

\section{Interventions}

There has been some debate in the Amazon as to what (if anything) should be done about $\mathrm{Hg}$ exposures through fish consumption. Some researchers have suggested that "normal" safe values, higher than those proposed by WHO, could be established in the Amazon 130, while others have claimed that despite the high $\mathrm{Hg}$ concentrations, daily consumption of large amounts of fish does not necessarily pose a health hazard 132,133. A contrasting opinion was expressed even in the early 1990s, when some authors recommended community-based interventions for both the occupational settings 2 and the environmental context 37 . Considering the potential for $\mathrm{Hg}$ induced deleterious health effects, these latter authors indicated that environmental biomonitoring would be pointless if not directed at clear action, and suggested that any approach seeking solutions to the high exposure problem should include a major educational component.

Most mitigation attempts have been undertaken to reduce the use of $\mathrm{Hg}$ in gold-mining activities. In recent years, national and international organizations have made efforts to introduce cleaner artisanal gold mining and extraction technologies in many developing countries 134 . These initiatives center on capacity- and awarenessbuilding about the links of small-scale gold-mining practices to human and ecosystem health 135 . Initial results from these activities in terms of reduction of $\mathrm{Hg}$ use and emissions through the adoption of homemade solutions have recently been reported in Africa 136

In the Amazon, during the early 1990s, major projects proposed alternative techniques to reduce $\mathrm{Hg}$ use and exposure in gold-mining ac- tivities 137,138, but the results on the efficiency of these interventions are not available. There are ongoing educational and capacity-building efforts in Brazil, Venezuela, Ecuador, and French Guiana 19,139 , but there are no reports on their success in reducing human exposure. These initiatives have encountered several barriers to change, the most important and challenging one being poverty; lack of resources and political support are also cited 140 . Hilson et al. 141 have pointed out that despite extensive research conducted over the past 15-20 years in Latin America and in Africa, most of the investigations have failed to identify appropriate mitigation measures, and education strategies have at best been marginally effective due to socioeconomic and poor living conditions in mining areas. The historical data in the present review clearly and sadly shows that despite many years of research, $\mathrm{Hg}$ exposure remains elevated throughout the Amazon region, corroborating the conclusions by Hilson et al. 141 .

To date, there has been little effort linked to the mitigation of $\mathrm{Hg}$ contamination through reduction in soil erosion, although there are current attempts to reforest areas in the Upper Tapajós region (Brazil), where gold mining was extensive and many studies have been carried out 142 . However, the increasing pressure to "develop" the Amazon through extensive exploitation of its natural resources and, more particularly, the recent push of the agricultural frontier, constitute a further barrier to reduction of deforestation and soil erosion 143,144.

A few efforts have addressed the question of fish-eating practices $19,128,145$, although in general there has been little focus on this issue possibly due to lack of political interest and the difficult trade-offs in public health regarding the reduction of toxic exposures through fish consumption. Indeed, these trade-offs have been the subject of much international debate over the last years because of the nutritional benefits from fish consumption 146,147,148,149. Modifying fish-eating habits through the use of fish advisories has constituted the most popular approach to reduce exposures and health risks in North America, Europe, and Japan, even if many policymakers consider such an approach an unfortunate and interim public health necessity 150 . In the Amazon, debate has been raging on the appropriateness of intervention 122,132,133 not only because fish is a very important dietary mainstay, but also because according to some authors 132,133 priority should rather be given to the high prevalence of other general health problems such as tropical diseases and intestinal parasites. Because of regional and seasonal variations in fish-Hg lev- 
els, as well as intercommunity differences in fish portions, Passos et al. 122 discuss the suitability of using fish advisories as a policy intervention in the Amazonian context and suggest that a risk management strategy that focuses solely on limiting the overall number of fish meals might unnecessarily deprive these populations of this important food source. Similar to the authors of studies in French Guiana 76, these authors 122 encourage close collaboration with local populations, public health authorities, and scientists to develop concrete recommendations and adopt measures to reduce the environmental sources of exposure. In the short term, and due to the high biodiversity of fish and fruit in the Amazon, dietary Hg exposures in the environment may be reduced through changes in fish-eating practices without necessarily limiting fish consumption frequency 122,145.

One such intervention was carried out in a village on the Tapajós River in Brazil. The investigators used a participatory strategy based on capacity building, aimed at maintaining fish consumption but shifting towards less contaminated fish species 145 . Through community involvement and education based on posters showing the status of $\mathrm{Hg}$ contamination in relation to fish species, villagers continued to eat the same quantity of fish, but decreased the proportion of carnivores, which resulted in a reduction in hair$\mathrm{Hg}$ levels of close to $40 \%$. An interesting aspect explored in this process was the role of community participation to achieve exposure reduction 145; using a social communication network analysis, these authors observed that participation was associated with awareness of the critical information that led to changing dietary habits towards the preferential consumption of the less contaminated fish species.

\section{New perspectives provided by the Amazonian research}

The studies performed in the Amazon have added important information to our knowledge on Hg sources, exposure, and effects. In this region, like elsewhere, Hg pollution is coming from multiple anthropogenic and natural sources, and the degree of contamination of the fishing resources is further influenced by the dynamics of the regional and local ecosystems. It was here that the first reports were made of dose-related neurofunctional deficits in adult humans chronically exposed to low doses of $\mathrm{Hg}$, below limits recommended by national and international bodies 151 . These effects were observed at exposure levels below the benchmark dose level (BMDL) for
blood-Hg $(58 \mu \mathrm{g} / \mathrm{L})$ that was used to calculate the U.S. Environmental Protection Agency (EPA) reference dose 25 , as well as the BMDL for hair-Hg $(14 \mu \mathrm{g} / \mathrm{g})$ used to determine the recently revised WHO reference dose 24 . Other health outcomes (cardiovascular, cytogenetic, and immunological) require more investigation.

The studies in the Amazon region have further advanced our knowledge on the relations between fish consumption, Hg intake, and exposure. Villagers' interest and participation in the studies, particularly women 145 , made it possible to examine the relations between diet and $\mathrm{Hg}$ exposure and demonstrate that fruit consumption modulates the relation between $\mathrm{Hg}$ intake and bioindicators of exposure. Further studies need to examine the underlying mechanisms. Investigations of the possible effects of elevated levels of Se, reported in this region, may provide some answers to the frequently asked questions about whether Se can influence Hg toxicity.

Despite the many remaining gaps, a picture of a complex situation, reflecting the biodiversity of the region, is emerging. In these populations that are already challenged by poor living and sanitary conditions, a high prevalence of tropical diseases and limited access to health care, further assault to physiological functions through exposure to $\mathrm{Hg}$ increases their vulnerability. Mitigation efforts in mining activities have hopefully reduced direct exposure of many miners and their families, but for the moment this is not reflected in a reduction of $\mathrm{Hg}$ concentrations in fish or humans. Deforestation remains extensive, among other reasons because of the encroachment of the agricultural frontier. In most Amazonian countries, public health authorities have not provided guidelines on fish consumption, possibly in part due to the importance of the nutritional value of fish and the consideration that the health effects of $\mathrm{Hg}$ are less severe than those of other health problems.

Could and/or should Hg reduction become a priority in the Amazon region? If one makes a long list of priorities, because of the multitude of environmental, social, and health problems, it might not be very near the top. But if one adopts an ecosystem approach that examines how it fits into current concerns over deforestation, environmental degradation from mining, social and economic development of the region, and improvement of human health, Hg reduction could be included as an outcome of research and intervention programs on many levels. To achieve this, we need to identify the social, political, and economic factors underlying deforestation and small-scale gold-mining operations $143,144,152$, as well as the socio-cultural factors that influence 
regional agricultural and forestry practices and diet $18,128,153$. We need to increase our understanding of the biogeochemical issues that will allow for control of the sources that contribute to the release of $\mathrm{Hg}$ into the aquatic ecosystems and increase our knowledge of the factors that influence $\mathrm{Hg}$ absorption and toxicity.

Finally, because of the ongoing severity of the problem, on a short-term basis we could take advantage of the high biodiversity of fish and fruits

\section{Resumo}

Este artigo examina questões sobre exposição humana ao mercúrio $(\mathrm{Hg})$ e seus efeitos adversos à saúde na Amazônia, com base em extensa revisão da literatura. Diferentes bioindicadores revelam uma ampla faixa de exposição, com teores médios de Hg em cabelo acima de 15 $\mu \mathrm{g} / \mathrm{g}$ em diversas comunidades amazônicas, situando-as dentre as mais expostas no mundo atualmente. Taxas de ingestão diária de Hg foram estimadas em alguns estudos e situam-se entre 1-2 $\mu \mathrm{g} / \mathrm{kg} / \mathrm{dia}$, consideravelmente acima das doses de referência estabelecidas pela USEPA $(0,1 \mu \mathrm{g} / \mathrm{kg} /$ dia $)$ ou pela OMS $(0,23 \mu \mathrm{g} / \mathrm{kg} / \mathrm{dia})$. Déficits neurocomportamentais e, em alguns casos, sinais clínicos relacionados à exposição mercurial têm sido relatados tanto em adultos quanto em crianças de diversos países amazônicos. Há também evidências de dano citogenético, mudanças imunológicas e toxicidade cardiovascular. Visto que peixe é altamente nutritivo e há diversas fontes de Hg nesta região, existe uma necessidade urgente de encontrar soluções realistas e viáveis capazes de reduzir os níveis de exposição e de risco tóxico, ao mesmo tempo mantendo os hábitos alimentares tradicionais, preservando a biodiversidade píscea e frutífera e melhorando a saúde das populações desfavorecidas e afetadas.

Intoxicação por Mercúrio; Exposição Ambiental; Ecossistema Amazônico readily available in these ecosystems, by coupling traditional knowledge and cultural practices to scientific information on $\mathrm{Hg}$ transmission from fish to humans and the factors that influence this relationship. The use of this information within a public health program could provide the means for modifying dietary habits and reduce Hg exposures, while maintaining the health benefits of a diet rich in fish intake.

\section{Contributors}

C. J. S. Passos designed the review project, conducted the bibliographic research, and wrote the report. D. Mergler participated in the design and planning of the manuscript and literature review and collaborated in drafting the text. Both authors read and approved the final version of the article.

\section{Acknowledgments}

The authors' research is supported by the International Development Research Center (IDCR, Canada) and the Canadian Institutes of Health Research (CIHR). C.J.S. Passos is recipient of a post-doctoral fellowship of the São Paulo State Research Foundation (FAPESP. São Paulo, Brazil). 


\section{References}

1. Cleary D. Anatomy of the Amazon Gold Rush. Iowa City: University of Iowa Press; 1990.

2. Branches FJ, Erickson,TB, Aks SE, Hryhorczuk DO. The price of gold: mercury exposure in the Amazonian rain forest. J Toxicol Clin Toxicol 1993, 31:295306.

3. Pfeiffer WC, Lacerda LD, Malm O, Souza CM, Silveira EG, Bastos WR. Mercury concentrations in inland water of gold-mining areas in Rondonia, Brazil. Sci Total Environ 1989; 87:233-40.

4. Malm O, Pfeiffer WC, Souza CMM, Reuther R. Mercury pollution due to gold mining in the Madeira River Basin, Brazil. Ambio 1990; 19:11-5.

5. Malm O. Gold mining as a source of mercury exposure in the Brazilian Amazon. Environ Res 1998; 77:73-8.

6. Guimarães JRD, Roulet M, Lucotte M, Mergler D. Mercury methylation along a lake-forest transect in the Tapajós river floodplain, Brazilian Amazon: seasonal and vertical variations. Sci Total Environ 2000; 261:91-8.

7. Roulet M, Lucotte M, Guimarães JRD, Rheault I. Methyl mercury in water, seston, and epiphyton of an Amazonian river and its floodplain, Tapajós River, Brazil. Sci Total Environ 2000; 261:43-59.

8. Veiga MM, Meech JA, Onate N. Mercury pollution from deforestation. Nature 1994; 368:815-6.

9. Roulet M, Lucotte M, Canuel R, Rheault I, Tran S, Goch YGF, et al. Distribution and partition of total mercury in waters of the Tapajós River Basin, Brazilian Amazon. Sci Total Environ 1998; 213:203-11.

10. Roulet M, Lucotte M, Saint-Aubin A, Tran S, Rheault I, Farella N, et al. The geochemistry of Hg in Central Amazonian soils developed on the Alter-do-Chão formation of the lower Tapajós river valley, Pará State, Brazil. Sci Total Environ 1998; 223:1-24.

11. Roulet M, Lucotte M, Farella N, Serique G, Coelho E, Passos CJS, et al. Effects of recent human colonization on the presence of mercury in Amazonian ecosystems. Water Air Soil Pollut 1999; 112: 297-313.

12. Roulet M, Lucotte M, Canuel R, Farella N, Courcelles M, Guimarães JRD, et al. Increase in mercury contamination recorded in lacustrine sediments following deforestation in the central Amazon. Chem Geol 2000; 165:243-66.

13. Farella N, Lucotte M, Louchouarn P, Roulet M. Deforestation modifying terrestrial organic transport in the Rio Tapajós, Brazilian Amazon. Org Geochem 2001; 32:1443-58.

14. Fadini PS, Jardim WF. Is the Negro River Basin (Amazon) impacted by naturally occurring mercury? Sci Total Environ 2001; 275:71-82.

15. Lacerda, LD, Souza M, Ribeiro MG. The effects of land use change on mercury distributions in soils of Alta Floresta, Southern Amazon. Environ Pollut 2004; 129:247-55.

16. Almeida MD, Lacerda LD, Bastos WR, Herrmann JC. Mercury loss from soils following conversion from forest to pasture in Rondônia, Western Amazon, Brazil. Environ Pollut 2005; 137:179-86.
17. Mainville N, Webb J, Lucotte M, Davidson R, Betancourt O, Cueva E, et al. Decrease of soil fertility and release of mercury following deforestation in the Andean Amazon, Napo River Valley, Ecuador. Sci Total Environ 2006; 368:88-98.

18. Farella N, Lucotte M, Davidson R, Daigl S. Mercury release from deforested soils triggered by base cation enrichment. Sci Total Environ 2006; 368:19-29.

19. Boudou A, Dominique Y, Cordier S, Fréry N. Les chercheurs d'or et la pollution par le mercure en Guyane française: conséquences environnementales et sanitaires. Environnement, Risques \& Santé 2006; 5:167-79.

20. Igata A. Epidemiological and clinical features of Minamata disease. Environ Res 1993; 63:157-69.

21. Clarkson TW. Mercury: major issues in environmental health. Environ Health Perspect 1992; 100:31-8.

22. Clarkson TW, Magos L. The toxicology of mercury and its chemical compounds. Crit Rev Toxicol 2006; 36:609-62.

23. Hachiya N. The history and the present of Minamata disease - entering the second half a century. Japanese Medical Association Journal 2006; 49:112-8.

24. Joint FAO/WHO Expert Committee on Food Additives. Sixty-first meeting. Summary and conclusions. ftp://ftp.fao.org/es/esn/jecfa/jecfa61sc.pdf (accessed on 21/Nov/2007).

25. National Research Council. Toxicological effects of methylmercury. Washington DC: National Academies Press; 2000.

26. Bastos WR, Gomes JPO, Oliveira RC, Almeida R, Nascimento EL, Bernardi JVE, et al. Mercury in the environment and riverside population in the Madeira River Basin, Amazon, Brazil. Sci Total Environ 2006; 368:344-51.

27. Pinheiro MCN, Oikawa T, Vieira JLF, Gomes MSV, Guimarães GA, Crespo-López ME, et al. Comparative study of human exposure to mercury in riverside communities in the Amazon region. Braz J Med Biol Res 2006; 39:411-4.

28. Da Silva ARB. Tapajós gold garimpos. In: VillasBôas RC, Beinhoff C, Da Silva AR, editors. Mercury in the Tapajós Basin. Rio de Janeiro: Centro de Tecnologia Mineral/Conselho Nacional de Desenvolvimento Científico e Tecnológico/ Subprograma de Tecnología Mineral, Programa Iberoamericano de Ciencia y Tecnología para el Desarrollo/Interagency Modeling and Atmospheric Assessment Center; 2001. p. 31-50.

29. Couto RCS, Câmara VM, Sabroza PC. Intoxicação mercurial: resultados preliminares em duas áreas garimpeiras - PA. Cad Saúde Pública 1988; 4: 301-15.

30. Boischio AAP, Barbosa A. Exposição ao mercúrio orgânico em populações ribeirinhas do Alto Madeira, Rondônia, 1991: resultados preliminares. Cad Saúde Pública 1993; 9:155-60.

31. Olivero J, Mendonza C, Mestre J. Mercurio en cabello de diferentes grupos ocupacionales en una zona de minería aurifera en el Norte de Colombia. Rev Saúde Pública 1995; 29:376-9. 
32. Cordier S, Grasmick C, Paquier-Passelaigue M, Mandereau L, Weber J-P, Jouan M. Mercury exposure in French Guiana: levels and determinants. Arch Environ Health 1998; 53:299-305.

33. Maurice-Bourgoin L, Quiroga I, Chincheros J, Courau P. Mercury distribution in waters and fishes of the upper Madeira Rivers and mercury exposure in riparian Amazonian populations. Sci Total Environ 2000; 260:73-86.

34. Webb J, Mainville N, Mergler D, Lucotte M, Betancourt O, Davidson R, et al. Mercury in fish-eating communities of the Andean Amazon, Napo River Valley, Ecuador. Ecohealth 2004; 1 Suppl 2:59-71.

35. Counter SA, Buchanan LH, Ortega F. Mercury levels in urine and hair of children in an Andean goldmining settlement. Int J Occup Environ Health 2005; 11:132-7.

36. Mohan S, Tiller M, van der Voet G, Kanhai H. Mercury exposure of mothers and newborns in Surinam: a pilot study. Clin Toxicol 2005; 43:101-4.

37. Eve E, Oliveira EF, Eve C. The mercury problem and diets in the Brazilian Amazon: planning a solution. Environ Conserv 1996; 23:133-9.

38. Leino T, Lodenius M. Human hair mercury levels in Tucurui area, State of Pará, Brazil. Sci Total Environ 1995; 175:119-25.

39. Santos ECO, Jesus IM, Brabo ES, Câmara VM, Loureiro ECB, Macarenhas AF, et al. Exposure to mercury in the urban population of Rio Branco City, State of Acre, Brazil. Bull Environ Contam Toxicol 2002; 69:314-9.

40. Passos CJ, Lucotte M, Queiroz A, Mergler D, Peleja R, Goch Y, et al. Condições sócio-econômicas e exposição ao mercúrio $(\mathrm{Hg})$ através do consumo de peixe: um estudo de caso em Santarém, Pará, Brasil. Revista Saúde Ambiente 2003; 6:3-11.

41. Santos ECO, Sá GC, Jesus IM, Brabo ES, Câmara VM, Lima MO, et al. Mercúrio no Rio Negro, Amazonas, Brasil - estudo preliminar de indicadores de exposição no pescado e em populações humanas. Cad Saúde Colet (Rio J) 2005; 13:225-36.

42. Davidson PW, Myers GJ, Cox C, Axtell C, Shamlaye C, Sloane-Reeves J, et al. Effects of prenatal and postnatal methyl mercury exposure from fish consumption on neurodevelopment: outcomes at 66 months of age in the Seychelles Child Development Study. JAMA 1998; 280:701-7.

43. Grandjean P, Weihe P, White RF, Debes F, Araki S, Yokoyama K, et al. Cognitive deficit in 7-year-old children with prenatal exposure to methyl mercury. Neurotoxicol Teratol 1997; 19:417-28.

44. Stern AH, Smith AE. An assessment of the cord blood:maternal blood methyl mercury ratio: implications for risk assessment. Environ Health Perspect 2003; 111:1465-70.

45. Barbosa AC, Boischio AAP, East GA, Ferrari I, Gonçalves A, Silva PRM, et al. Mercury contamination in the Brazilian Amazon: environmental and occupational aspects. Water Air Soil Pollut 1995; 80: 109-21.

46. Palheta D, Taylor A. Mercury in environmental and biological samples from a gold mining area in the Amazon region of Brazil. Sci Total Environ 1995; 168:63-9.
47. Hurtado J, Gonzales GF, Steenland K. Mercury exposures in informal gold miners and relatives in southern Peru. Int J Occup Environ Health 2006; 12:340-5.

48. Rosa RMSS, Muller RCS, Alves CN, Sarkis JES, Bentes MHS, Brabo E, et al. Determination of total mercury in workers' urine in gold shops of Itaituba, Pará State, Brazil. Sci Total Environ 2000; 261:169-76.

49. Jesus IM, Santos ECO, Brabo ES, Loureiro ECB, Câmara VM, Mascarenhas AF, et al. Exposure to elemental mercury in urban workers and gold miners from the Tapajós region, Pará, Brazil. Bull Environ Contam Toxicol 2001; 67:317-23.

50. Harari R, Forastiere F, Axelson O. Unacceptable "occupational" exposure to toxic agents among children in Ecuador. Am J Ind Med 1997; 32:185-9.

51. Apostoli P, Cortesi I, Mangili A, Elia G, Drago I, Gagliardi $\mathrm{T}$, et al. Assessment of reference values for mercury in urine: the results of an Italian polycentric study. Sci Total Environ 2002; 289:13-24.

52. Berglund M, Lind B, Bjornberg A, Palm B, Einarsson $\mathrm{O}$, Vahter M. Inter-individual variations of human mercury exposure biomarkers: a cross-sectional assessment. Environ Health 2005; 4:20.

53. Johnsson C, Schutz A, Sallsten G. Impact of consumption of freshwater fish on mercury levels in hair, blood, urine, and alveolar air. J Toxicol Environ Health A 2005; 68:129-40.

54. Levy M, Schwartz S, Dijak M, Weber J-P, Tardif R, Rouah F. Childhood urine mercury excretion: dental amalgam and fish consumption as exposure factors. Environ Res 2004; 94:283-90.

55. Ohno T, Sakamoto M, Kurosawa T, Dakeishi M, Iwata T, Murata K. Total mercury levels in hair, toenail, and urine among women free from occupational exposure and their relations to renal tubular function. Environ Res 2007; 103:191-7.

56. Passos CJS, Mergler D, Lemire M, Fillion M, Guimarães JRD. Fish consumption and bioindicators of inorganic mercury exposure. Sci Total Environ 2007; 373:68-76.

57. Veiga MM, Bermudes D, Pacheco-Ferreira H, Pedroso LRM, Gunson AJ, Berrios G, et al. Mercury pollution from artisanal gold mining in Block B, El Callao, Bolívar State, Venezuela. In: Pirrone N, Mahaffey K, editors. Dynamics of mercury pollution on regional and global scales: atmospheric processes, human exposure around the world. Norwell: Springer; 2005. p. 421-50.

58. Gammons CH, Slotton DG, Gerbrandt B, Weight W, Young CA, McNearny RL, et al. Mercury concentrations of fish, river water, and sediment in the Río Ramis-Lake Titicaca watershed, Peru. Sci Total Environ 2006; 368:637-48.

59. Hylander LD, Grohn J, Tropp M, Vikstrom A, Wolpher H, Silva EC, et al. Fish mercury increase in Lago Manso, a new hydroelectric reservoir in tropical Brazil. J Environ Manage 2006; 81:155-66.

60. Betancourt O, Narváez A, Roulet M. Small-scale gold mining in the Puyango River Basin, Southern Ecuador: a study of environmental impacts and human exposures. Ecohealth 2005; 2:323-32. 
61. Do Valle CM, Santana GP, Augusti R, Filho FBE, Windmoller CC. Speciation and quantification of mercury in oxisol, ultisol, and spodosol from Amazon (Manaus, Brazil). Chemosphere 2005; 58: 779-92.

62. Do Valle CM, Santana GP, Windmoller CC. Mercury conversion processes in Amazon soils evaluated by thermodesorption analysis. Chemosphere 2006; 65:1966-75.

63. Dórea JG, Barbosa AC, Ferrari I, Souza JR. Mercury in hair and fish consumed by riparian women of the Rio Negro, Brazil. Int J Environ Health Res 2003; 13:239-48.

64. Dórea JG, Barbosa AC, Silva GS. Fish mercury bioaccumulation as a function of feeding behavior and hydrological cycles of the Rio Negro, Amazon. Comp Biochem Physiol C Toxicol Pharmacol 2006; 142:275-83.

65. Malm O, Branches FJP, Akagi H, Castro MB, Pfeiffer WC, Harada M, et al. Mercury and methyl mercury in fish and human hair from the Tapajós river basin, Brazil. Sci Total Environ 1995; 175:141-50.

66. Barbosa AC, Garcia AM, Souza JR. Mercury contamination in hair of riverine populations of Apiacás reserve in the Brazilian Amazon. Water Air Soil Pollut 1997; 97:1-8.

67. Kehrig HA, Malm O, Akagi H. Methyl mercury in hair samples from different riverine groups, Amazon, Brazil. Water Air Soil Pollut 1997; 97:17-29.

68. Lebel J, Roulet M, Mergler D, Lucotte M, Larribe F. Fish diet and mercury exposure in a riparian Amazonian population. Water Air Soil Pollut 1997; 97:31-44.

69. Kehrig HA, Malm O, Akagi H, Guimarães JRD, Torres JPM. Methyl mercury in fish and hair samples from the Balbina Reservoir, Brazilian Amazon. Environ Res 1998; 77:84-90.

70. Hacon S, Yokoo E, Valente J, Campos RC, Silva VA, Menezes ACC, et al. Exposure to mercury in pregnant women from Alta Floresta - Amazon Basin, Brazil. Environ Res 2000; 84:204-10.

71. Pinheiro MCN, Guimarães GA, Nakanishi J, Oikawa T, Vieira JL, Quaresma M, et al. Avaliação da contaminação mercurial mediante análise do teor de Hg total em amostras de cabelo em comunidades ribeirinhas do Tapajós, Pará, Brasil. Rev Soc Bras Med Trop 2000; 33:181-4.

72. Dolbec J, Mergler D, Larribe F, Roulet M, Lebel J, Lucotte M. Sequential analysis of hair mercury levels in relation to fish diet of an Amazonian population, Brazil. Sci Total Environ 2001; 271:87-97.

73. Santos ECO, Câmara VM, Brabo ES, Loureiro ECB, Jesus IM, Fayal K, et al. Avaliação dos níveis de exposição ao mercúrio entre índios Pakaanóva, Amazônia, Brasil. Cad Saúde Pública 2003; 19:199206.

74. Sing KA, Hryhorczuk DO, Saffirio G, Sinks T, Paschal DC, Chen EH. Environmental exposure to organic mercury among Makuxi in the Amazon basin. Int J Occup Environ Health 1996; 2:165-71.

75. Guimarães JRD, Fostier AH, Forti MC, Melfi JA, Kehrig H, Mauro JBN, et al. Mercury in human and environmental samples from two lakes in Amapá, Brazilian Amazon. Ambio 1999; 28:296-301.
76. Fréry N, Maury-Brachet R, Maillot E, Deheeger M, Mérona B, Boudou A. Gold mining activities and mercury contamination of native Amerindian communities in French Guiana: key role of fish in dietary uptake. Environ Health Perspect 2001; 109:449-56.

77. Hacon S, Rochedo ER, Campos R, Rosales G, Lacerda LD. Risk assessment of mercury in Alta Floresta. Amazon Basin - Brazil. Water Air Soil Pollut 1997; 97:91-105.

78. Bastos WR, De Almeida R, Dórea JG, Barbosa AC. Annual flooding and fish-mercury bioaccumulation in the environmentally impacted Rio Madeira (Amazon). Ecotoxicology 2007; 16:341-6.

79. Régine M-B, Durrieu G, Dominique Y, Boudou A. Mercury distribution in fish organs and food regimes: significant relationships from twelve species collected in French Guiana (Amazonian basin). Sci Total Environ 2006; 368:262-70.

80. Da Silva DS, Lucotte M, Roulet M, Poirier H, Mergler D, Crossa M. Mercury in fish of the Tapajós River in the Brazilian Amazon. INTERFACEHS Revista de Gestão Integrada em Saúde do Trabalho e Meio Ambiente 2006; 1(1).

81. Boischio AAP, Henshel DS. Risk assessment of mercury exposure through fish consumption by the riverside people in the Madeira Basin, Amazon, 1991. Neurotoxicology 1996; 17:169-75.

82. Lebel J, Mergler D, Lucotte M, Amorim M, Dolbec J, Miranda D, et al. Evidence of early nervous system dysfunctions in Amazonian populations exposed to low-level methyl mercury. Neurotoxicology 1996; 17:157-68.

83. LebelJ, MerglerD, BranchesF, Lucotte M,Amorim M, Larribe F, et al. Neurotoxic effects of low-level methyl mercury contamination in the Amazonian Basin. Environ Res 1998; 79:20-32.

84. Dolbec J, Mergler D, Passos CJS, Morais SS, Lebel J. Methyl mercury exposure affects motor performance of a riverine population of the Tapajós River, Brazilian Amazon. Int Arch Occup Environ Health 2000; 73:195-203.

85. Yokoo EM, Valente JG, Grattan L, Schimidt SL, Platt I, Silbergeld EK. Low level methyl mercury exposure affects neuropsychological functions in adults. Environ Health 2003; 2:8.

86. Silveira LCL, Ventura DF, Pinheiro MCS. Toxicidade mercurial - avaliação do sistema visual em indivíduos expostos a níveis tóxicos de mercúrio. Ciênc Cult (São Paulo) 2004; 56:36-8.

87. Grandjean P, White RF, Nielsen A, Cleary D, Santos ECO. Methyl mercury neurotoxicity in Amazonian children downstream from gold mining. Environ Health Perspect 1999; 107:587-91.

88. Cordier S, Garel M, Mandereau L, Morcel H, Doineau P, Gosme-Seguret $S$, et al. Neurodevelopmental investigations among methyl mercuryexposed children in French Guiana. Environ Res 2002; 89:1-11.

89. Tavares LMB, Câmara VM, Malm O, Santos ECO. Performance on neurological development tests by riverine children with moderate mercury exposure in Amazonia, Brazil. Cad Saúde Pública 2005; 21:1160-7. 
90. Marques RC, Dórea JG, Bastos WR, Rebelo MF, Fonseca MF, Malm O. Maternal mercury exposure and neuro-motor development in breastfed infants from Porto Velho (Amazon), Brazil. Int J Hyg Environ Health 2007; 210:51-60.

91. Debes F, Budtz-Jorgensen E, Weihe P, White RF, Grandjean P. Impact of prenatal methyl mercury exposure on neurobehavioral function at age 14 years. Neurotoxicol Teratol 2006; 28:363-75.

92. Kjellstrom T, Kennedy P, Wallis S, Mantell C. Physical and mental development of children with prenatal exposure to mercury from fish, stage I: preliminary tests at age 4 . Solna: National Swedish Environmental Protection Board; 1986. (Report, 3080).

93. Kjellstrom T, Kennedy P, Wallis S, Stewart A, Friberg L, Lind B, et al. Physical and mental development of children with prenatal exposure to mercury from fish, stage II: interview and psychological tests at age 6. Solna: National Swedish Environmental Protection Board; 1989. (Report, 3642).

94. Saint-Amour D, Roy M-S, Bastien C, Ayotte P, Dewailly É, Desprès C, et al. Alterations of visual evoked potentials in pre-school children exposed to methyl mercury and polychlorinated biphenyls from a marine diet. Neurotoxicology 2006; 27 : 567-78.

95. Murata K, Sakamoto M, Nakai K, Dakeishi M, Iwata T, Liu X-J, et al. Subclinical effects of prenatal methyl mercury exposure on cardiac autonomic function in Japanese children. Int Arch Occup Environ Health 2006; 79:379-86.

96. Counter SA, Buchanan LH, Laurell G, Ortega F. Blood mercury and auditory neuro-sensory responses in children and adults in the Nambija gold-mining area of Ecuador. Neurotoxicology 1998; 19:185-96

97. Counter SA. Elevated blood mercury and neurootological observations in children of the Ecuadorian gold-mines. J Toxicol Environ Health A 2002; 65:149-63.

98. Arruda AGO, Câmara V, Lima MAMT. Avaliação otoneurológica em uma população exposta ao metilmercúrio. Arq Int Otorrinolaringol 2002; 6:1.

99. Harada M, Nakanishi J, Yasoda E, Pinheiro MCN, Oikawa T, Guimarães GA, et al. Mercury pollution in the Tapajós River Basin, Amazon: mercury level of head hair and health effects. Environ Int 2001; 27:285-90.

100. Pacheco-Ferreira H. Mercúrio na Amazônia: efeitos sobre a saúde das populações ribeirinhas [Doctoral Dissertation]. Belém: Núcleo de Altos Estudos Amazônicos, Universidade Federal do Pará; 2001.

101. Carta P, Flore C, Alinovi R, Ibba A, Tocco MG, Aru $\mathrm{G}$, et al. Sub-clinical neurobehavioral abnormalities associated with low level of mercury exposure through fish consumption. Neurotoxicology 2003; 24:617-23.

102. Lucchini R, Calza S, Camerino D, Carta P, Decarli A, Parrinello G, et al. Application of a latent variable model for a multicenter study on early effects due to mercury exposure. Neurotoxicology 2003; 24:605-16.
103. Amorim MIM, Mergler D, Bahia MO, Dubeau H, Miranda D, Lebel J, et al. Cytogenetic damage related to low levels of methyl mercury contamination in the Brazilian Amazon. An Acad Bras Ciênc 2000; 72:497-507.

104. Bahia MO, Corvelo TC, Mergler D, Burbano RR, Lima PDL, Cardoso PCS, et al. Environmental biomonitoring using cytogenetic endpoints in a population exposed to mercury in the Brazilian Amazon. Environ Mol Mutagen 2004; 44:346-9.

105. Crompton P, Ventura AM, Souza JM, Santos E, Strickland GT, Silbergeld E. Assessment of mercury exposure and malaria in a Brazilian Amazon riverine community. Environ Res 2002; 90:69-75.

106. Silva IA, Nyland JF, Gorman A, Perisse A, Ventura AM, Santos ECO, et al. Mercury exposure, malaria, and serum antinuclear/antinucleolar antibodies in Amazon populations in Brazil: a cross-sectional study. Environ Health 2004; 3:11.

107. Alves MFA, Fraiji NA, Barbosa AC, Lima DSN, Souza JR, Dórea JG, et al. Fish consumption, mercury exposure and serum antinuclear antibody in Amazonians. Int J Environ Health Res 2006; 16: 255-62.

108. Silbergeld EK, Silva IA, Nyland JF. Mercury and autoimmunity: implications for occupational and environmental health. Toxicol Appl Pharmacol 2005; 207(2 Suppl):282-92.

109. Dórea JG, Souza JR, Rodrigues P, Ferrai I, Barbosa AC. Hair mercury (signature of fish consumption) and cardiovascular risk in Mundurucu and Kayabi Indians of Amazonia. Environ Res 2005; 97: 209-19.

110. Fillion M, Mergler D, Passos CJS, Larribe F, Lemire M, Guimarães JRD. A preliminary study of mercury exposure and blood pressure in the Brazilian Amazon. Environ Health 2006; 5:29.

111. Guallar E, San-Gallardo MI, Van't Veer P, Bode P, Aro A, Gómes-Aracena J, et al. Mercury, fish oils, and the risk of myocardial infarction. $\mathrm{N}$ Engl J Med 2002; 347:1747-54.

112. Virtanen JK, Rissanen TH, Voutilainen S, Tuomainen T-P. Mercury as a risk factor for cardiovascular diseases. J Nutr Biochem 2007; 18:75-85.

113. Passos CJS, Mergler D, Gaspar E, Morais S, Lucotte $\mathrm{M}$, Larribe F, et al. Eating tropical fruit reduces mercury exposure from fish consumption in the Brazilian Amazon. Environ Res 2003; 93:123-30.

114. Passos C, Mergler D, Larribe F. Response to "fruits, fish, and mercury: further considerations". Environ Res 2004; 96:102-8.

115. Passos CJS, Mergler D, Fillion M, Lemire M, Mertens F, Guimarães JRD, et al. Epidemiologic confirmation that fruit consumption influences mercury exposure in the Brazilian Amazon. Environ Res 2007; 105:183-93.

116. Strain JJ, Bonham MP, Duffy EM, Wallace JMW, Robson PJ, Clarkson TW, et al. Nutrition and neurodevelopment: the search for candidate nutrients in the Seychelles Child Development Nutrition Study. Seychelles Medical and Dental Journal 2004; 7:77-83.

117. Watanabe C. Modification of mercury toxicity by selenium: practical importance? Tohoku J Exp Med 2002; 196:71-7. 
118. Vasconcelos MBA, Bode P, Paletti G, Catharino MGM, Ammerlaan K, Saiki M, et al. Determination of mercury and selenium in hair samples of Brazilian Indian populations living in the Amazonic region by NAA. Journal of Radioanalytical and Nuclear Chemistry 2000; 244:81-5.

119. Campos MS, Sarkis JES, Muller RCS, Brabo ES, Santos EO. Correlation between mercury and selenium concentrations in Indian hair from Rondônia State, Amazon region, Brazil. Sci Total Environ 2002; 287:155-61.

120. Pinheiro MCN, Muller RCS, Sarkis JE, Vieira JLF, Oikawa T, Gomes MSV, et al. Mercury and selenium concentrations in hair samples of women in fertile age from Amazon riverside communities. Sci Total Environ 2005; 349:284-8.

121. Lemire M, Mergler D, Fillion M, Passos CJS, Guimarães JRD, Davidson R, et al. Elevated blood selenium levels in the Brazilian Amazon. Sci Total Environ 2006; 366:101-11.

122. Passos CJS, Silva DS, Lemire M, Fillion M, Guimarães JRD, Lucotte $\mathrm{M}$, et al. Daily mercury intake in fish-eating populations in the Brazilian Amazon. J Expo Sci Environ Epidemiol 2008; 18:76-87.

123. Feeney MJ. Fruits and the prevention of lifestylerelated diseases. Clin Exp Pharmacol Physiol 2004; 31 Suppl 2:S11-3.

124. Del Pozo-Insfran D, Brenes CH, Talcott ST. Phytochemical composition and pigment stability of Açai (Euterpe oleracea Mart.). J Agric Food Chem 2004; 52:1539-45.

125. Del Pozo-Insfran D, Percival SS, Talcott ST. Açai (Euterpe oleracea Mart.) polyphenolics in their glycoside and aglycone forms induce apoptosis of HL-60 leukemia cells. J Agric Food Chem 2006; 54:1222-9.

126. Andrade EH, Zoghbi MGB, Maia JGS, Fabricius H, Marx F. Chemical characterization of the fruit of Annona squamosa L. occurring in the Amazon. J Food Compost Anal 2001; 14:227-32.

127. Lichtenthaler R, Rodrigues RB, Maia JGS, Papagiannopoulos M, Fabricius H, Marx F. Total oxidant scavenging capacities of Euterpe oleracea Mart. (Açai) fruits. Int J Food Sci Nutr 2005; 56:53-64.

128. Boischio AAP, Henshel D. Fish consumption, fish lore, and mercury pollution - risk communication for the Madeira River people. Environ Res 2000; 84:108-26.

129. Santos ECO, Jesus IM, Brabo ES, Loureiro EB, Mascarenhas AFS, Weirich J, et al. Mercury exposures in riverside Amazon communities in Pará, Brazil. Environ Res 2000; 84:100-7.

130. Santos ECO, Câmara VM, Jesus IM, Brabo ES, Loureiro ECB, Mascarenhas AFS, et al. A contribution to the establishment of reference values for total mercury levels in hair and fish in Amazonia. Environ Res 2002; 90:6-11.

131. Santos EO, Loureiro ECB, Jesus IM, Brabo E, Silva RSU, Soares MCP, et al. Diagnóstico das condições de saúde de uma comunidade garimpeira na região do Rio Tapajós, Itaituba, Pará, Brasil, 1992. Cad Saúde Pública 1995; 11:212-25.
132 Dórea JG. Fish are central in the diet of Amazonian riparians: should we worry about their mercury concentrations? Environ Res 2003; 92: 232-44.

133. Dórea JG. Cassava cyanogens and fish mercury are high but safely consumed in the diet of native Amazonians. Ecotoxicol Environ Saf 2004; 57:24856.

134. Veiga M, Baker R. Protocols for environmental and health assessment of mercury released by artisanal and small-scale gold miners. http://www. unites.uqam.ca/gmf/intranet/gmp/index_gmp. htm (accessed on 30/Nov/2007).

135. Spiegel SJ, Veiga MM. Building capacity in smallscale mining communities: health, ecosystem sustainability, and the Global Mercury Project. Ecohealth 2005; 2:361-9.

136. Spiegel SJ, Savornin O, Shoko D, Veiga MM. Mercury reduction in Munhena, Mozambique: homemade solutions and the social context for change. Int J Occup Environ Health 2006; 12:215-21.

137. Imperial College Consultants. Informal gold mining along the Amazon in Brazil - full report. http://www.imperial-consultants.co.uk/example. php?id=24 (accessed on 01/Jun/2007).

138. Cleary D. Mercury contamination and health risk in the Brazilian Amazon: an ethical dilemma. Rev Inst Med Trop São Paulo 1996; 38:247-8.

139. Veiga MM. Unidades de demostración y campaña de educación para mineros artesanales de oro. In: II Foro Internacional sobre la Minería en Pequeña Escala. http://www.unites.uqam.ca/ gmf/intranet/gmp/index_gmp.htm (accessed on 30/Nov/2007).

140. Kligerman DC, La Rovere EL, Costa MA. Management challenges on small-scale gold mining activities in Brazil. Environ Res 2001; 87:181-98.

141. Hilson G, Hilson CJ, Pardie S. Improving awareness of mercury pollution in small-scale gold mining communities: challenges and ways forward in rural Ghana. Environ Res 2007; 103:275-87.

142. Global Mercury Project. Removal of barriers to the introduction of cleaner artisanal gold mining and extraction technologies. http://www.unites. uqam.ca/gmf/intranet/gmp/index_gmp.htm (accessed on 01/Jun/2007).

143. Nepstad DC, Stickler CM, Almeida OT. Globalization of the Amazon soy and beef industries: opportunities for conservation. Conserv Biol 2006; 20:1595-603.

144. Soares-Filho BS, Nepstad DC, Curran LM, Cerqueira GC, Garcia RA, Ramos CA, et al. Modelling conservation in the Amazon basin. Nature 2006; 440:520-3.

145. Mertens F, Saint-Charles J, Mergler D, Passos CJ, Lucotte M. A network approach for analysing and promoting equity in participatory ecohealth research. EcoHealth 2005; 2:113-26.

146. Duhaime G, Chabot M, Fréchette P, Robichaud V, Proulx S. The impact of dietary changes among the Inuit of Nunavik (Canada): a socioeconomic assessment of possible public health recommendations dealing with food contamination. Risk Anal 2004; 24:1007-18. 
147. Levenson CW, Axelrad DM. Too much of a good thing? Update on fish consumption and mercury exposure. Nutr Rev 2006; 64:139-45.

148. Marien K, Stern AH. An examination of the tradeoffs in public health resulting from the use of default exposure assumptions in fish consumption advisories. Environ Res 2005; 98:258-67.

149. Mozaffarian D, Rimm EB. Fish intake, contaminants, and human health: evaluating the risks and the benefits. JAMA 2006; 296:1885-99.

150. Swain EB, Jakus PM, Rice G, Lupi F, Maxson PA, Pacyna JM, et al. Socioeconomic consequences of mercury use and pollution. Ambio 2007; 36: 45-61.

151. Mergler D, Anderson HA, Chan LHM, Mahaffey KR, Murray M, Sakamoto M, et al. Methyl mercury exposure and health effects in humans: a worldwide concern. Ambio 2007; 36:3-11.

152. Spiegel SJ, Yassi A, Spiegel JM, Veiga MM. Reducing mercury and responding to the global gold rush. Lancet 2005; 366:2070-2.

153. Farella N, Davidson R, Lucotte M, Daigle S. Nutrient and mercury variations in soils from family farms of the Tapajós region (Brazilian Amazon): recommendations for better farming. Agric Ecosyst Environ 2007; 120:449-62.

154. Vasconcelos MBA, Saiki M, Paletti G, Pinheiro RMM, Baruzzi RG, Spindel R. Determination of mercury in head hair of Brazilian population groups by neutron activation analysis. Journal of Radioanalytical and Nuclear Chemistry 1994; 179:369-76.

155. Barbosa AC, Silva SRL, Dórea JG. Concentrations of mercury in hair of indigenous mothers and infants from the Amazon Basin. Arch Environ Contam Toxicol 1998; 34:100-5.
156. Boischio AAP, Cernichiari E. Longitudinal hair mercury concentrations in riverside mothers along the upper Madeira River (Brazil). Environ Res 1998; 77:79-83.

157. Barbosa AC, Jardim W, Dórea JG, Forsberg B, Souza J. Hair mercury speciation as a function of gender, age, and body mass index in inhabitants of the Negro River basin, Amazon, Brazil. Arch Environ Contam Toxicol 2001; 40:439-44.

158. Boischio AAP, Mergler D, Passos CJ, Gaspar E, Morais. Segmental hair mercury evaluation among mothers, their babies and breast milk along the Tapajós River, Amazon, Brazil. Environ Sci 2003; 10:107-20.

159. Dórea JG, Barbosa AC, Ferrari I, Souza JR. Fish consumption (hair mercury) and nutritional status of Amazonian Amerindian children. Am J Hum Biol 2005; 17:507-14.

160. Pinheiro MCN, Crespo-López ME, Vieira JLF, Oikawa T, Guimarães GA, Araújo CC, et al. Mercury pollution and childhood in Amazon riverside villages. Environ Int 2007; 33:56-61.

161. Bidone ED, Castilhos ZC, Santos TJS, Souza TMC, Lacerda LD. Fish contamination and human exposure to mercury in Tartarugalzinho River, Amapá State, Northern Amazon, Brazil. A screening approach. Water Air Soil Pollut 1997; 97:9-15.

162. Hacon S, Farias RA, Barrocas P, Campos RC, Wasserman J, Argento R. Avaliação da exposição humana ao mercúrio na região norte de Mato Grosso - Amazônia Legal. Cad Saúde Colet (Rio J) $2005 ; 13: 837-54$.

Submitted on 26/Feb/2008

Approved on 29/Apr/2008 